\title{
ГЕОХИМИЧЕСКИЕ КРИТЕРИИ ИЗВЕСТКОВО-ЩЕЛОЧНЫХ ИНТРУЗИВНЫХ МАГМ, ПЕРСПЕКТИВНЫХ НА ОБНАРУЖЕНИЕ МЕДНО-ПОРФИРОВЫХ МЕСТОРОЖДЕНИЙ НА СЕВЕРО-ВОСТОКЕ РОССИИ
}

\author{
В. В. Акинин ${ }^{1}$ Н. В. Бердников ${ }^{2}$, Г. О. Ползуненков ${ }^{1}$, А. Н. Глухов, Е. Е. Колова \\ ${ }^{\prime}$ ФББУН Северо-Восточный комплексный научно-исследовательский институт \\ им. Н. А. Шило ДВО РАН, г. Магадан \\ ${ }^{2}$ ФГБУН Институт тектоники и геофизики им. Ю. А. Косыгина, г. Хабаровск \\ E-mail: akinin@neisri.ru
}

\begin{abstract}
Приведена краткая геохимическая характеристика интрузивных пород известково-щелочной серии из главных мезозойских магматических поясов Северо-Востока России (Колымского, Чукотского, Олойского, Удско-Мургальского и Охотско-Чукотского). Используя известные геохимические параметры $(\mathrm{Sr} / \mathrm{Y}$ и $\mathrm{V} / \mathrm{Sc})$ рудоносных магм, с которыми генетически связаны медно-порфировые с золотом месторождения мира, авторы выявили наиболее перспективные в этом отношении раннемеловые магматические комплексы в Магаданской области и на Чукотке (охотский, наяханский и егдэгкычский).
\end{abstract}

Ключевые слова: медно-порфировые месторождения, критерии, магматизм, геохимия, Северо-Восток России.

DOI: $10.34078 / 1814-0998-2020-1-3-10$

\section{ВВЕДЕНИЕ}

Генезис большинства медно-порфировых месторождений мира связан с гидротермальномагматической эволюцией известково-щелочных магм, формирующихся в надсубдукционных условиях на конвергентных континентальных окраинах (Sillitoe, 1972; Richards, 2003). Связь минерализации с магматизмом в этом типе месторождений не вызывает сомнений у большинства исследователей, источник рудных элементов, серы и флюидов прямо ассоциирует с магмами (Hedenquist, Lowenstern, 1994; Richards, 2003; Pettke et al., 2010). Крупнейшие и хорошо изученные $\mathrm{Cu}-\mathrm{Mo-порфировые} \mathrm{ме-}$ сторождения сконцентрированы в Андийском окраинно-континентальном поясе (Чили), в эоцен-олигоценовой истории развития которого установлены эпизоды интенсивных деформаций, кристаллического сжатия, утолщения коры, сопровождающиеся развитием «адакитовых» гео-

(C) Акинин В. В., Бердников Н. В., Ползуненков Г. О., Глухов А. Н., Колова Е. Е.., 2020 химических характеристик (высокие $\mathrm{Sr} / \mathrm{Y}, \mathrm{V} / \mathrm{Sc}$, $\mathrm{La} / \mathrm{Yb}, \mathrm{Al}_{2} \mathrm{O}_{3} / \mathrm{TiO}_{2}$ ) в кислых магмах, ассоциирующих в пространстве и времени с промышленной $\mathrm{Cu}-\mathrm{Au}$ минерализацией (Kay et al., 1991; Oyarzun et al., 2001; Sillitoe, Perelly, 2005; Chiaradia et al., 2009; Loucks, 2014). Особый интерес вызывает такой геохимический параметр магм, как отношение $\mathrm{Sr} / \mathrm{Y}$. Высокое $\mathrm{Sr} / \mathrm{Y}$ отношение в магмах и другие «адакитовые» характеристики связывают в последнее время не обязательно с плавлением субдуцирующего слэба, напротив, это может быть результатом магматической эволюции на глубинных средне- и нижнекоровых уровнях с фракционированием амфибола (например, Chiaradia et al., 2012; Chiaradia, 2015).

На Северо-Востоке России, где широко проявлены позднемезозойские окраинно-континентальные магматические пояса, стоило бы по аналогии с Андийским поясом ожидать такого же широкого проявления медно-порфировых месторождений. Однако в текущее время такого не наблюдается, что может быть связано либо с недостаточной активизацией поисков и разведки в этом направлении из-за того, что традицион- 
но главный акцент делался на золото и серебро, либо с иными, отличными от андийской обстановки, тектономагматическими условиями проявлений.

Настоящая статья посвящена краткой геохимической характеристике главных магматических поясов Северо-Востока России, с особым акцентом на такие хорошо зарекомендовавшие себя в качестве прогнозно-поисковых критериев, как отношения $\mathrm{Sr} / \mathrm{Y}$ и V/Sc. В результате наметились наиболее перспективные в этом отношении магматические комплексы на Чукотке и в Северном Приохотье.

\section{МЕТОДЫ ИССЛЕДОВАНИЙ}

Для анализа геохимических особенностей магматических пород Северо-Востока России использована авторская база данных, содержащая наши неопубликованные материалы, а также опубликованные результаты (Layer et al., 2001; Горячев, Бердников, 2006; Трунилина и др., 2007; Акинин, Миллер, 2011; Шпикерман и др., 2016; Soloviev et al., 2019) рентгенофлюоресцентного и ICP-MS анализа по 850 образцам.

Рентгенофлюоресцентный анализ (XRF) горных пород на главные и примесные (Rb, $\mathrm{Sr}, \mathrm{Zr}, \mathrm{Y}$, $\mathrm{Nb})$ элементы выполнен в ЦКП СВКНИИ ДВО PAH (г. Магадан) на спектрометрах SRM-25 и VRA-30 с применением стандартной процедуры, при этом погрешности определения стандартов по главным элементам не превышали $0.4 \%$ для $\mathrm{SiO}_{2}$ и $0.2 \%$ для остальных оксидов, для $\mathrm{Sr}$ и $\mathrm{Zr}$ погрешность не превышала 5-6\%. Анализ пород на широкий круг примесных элементов, включая редкоземельные, выполнен методом ICP-MS в Хабаровском инновационно-аналитическом центре ИТиГ ДВО РАН (г. Хабаровск) с пределом обнаружения $1 \mathrm{ppb}$. Повторяющиеся измерения стандартов BHVO-1, AGV-1, JG-2, JA-2, JB-2 и BIR-1 показали погрешности не более 5-10\%.

Концентрации $\mathrm{Sr}$, определенные для одних и тех же образцов методами XRF и ICP-MS, хорошо коррелируют (коэффициент корреляции равен 0.93), в то время как для концентрации Y корреляция неудовлетворительная $\left(\mathrm{R}^{2}=0.35\right)$. По этой причине мы использовали для расчета $\mathrm{Sr} / \mathrm{Y}$, а также V/Sc главным образом ICP-MS анализы.

Для корректного использования интересующих нас важных геохимических отношений $\mathrm{Sr} / \mathrm{Y}$ и V/Sc в базе была проведена разбраковка и оставлены удовлетворяющие по следующим критериям данные (Loucks, 2014): 1) потери при прокаливании менее 3.5 мас.\%; 2) сумма главных элементов (оксидов) в интервале 97.5101.5 мас.\%; 3) отсутствие значительного гидротермального изменения плагиоклазов, о чем свидетельствуют наблюдения в шлифах; 4) отсутствие кумулатов с $\mathrm{Eu} / \mathrm{Eu}^{*}>1.3$ и $\mathrm{Al}_{2} \mathrm{O}_{3}$
$>20$ мас.\%; 5) все анализы попадают в поле толеитовых или низко- и высококалиевых известково-щелочных серий и не принадлежат к фельдшпатоид-нормативным щелочным породам или ортопироксен-нормативным, или высококалиевым абсарокит-шошонит-банакитовым сериям.

\section{ГЕОЛОГИЯ}

Главные позднемезозойские окраинно-континентальные магматические пояса СевероВостока России, в которых известны меднопорфировые проявления и месторождения, включают Олойский (ОЛ), Удско-Мургальский (УМ) и Охотско-Чукотский (ОЧ) вулкано-плутонические пояса. Геодинамическая природа поясов традиционно интерпретировалась как надсубдукционная (Парфенов, 1984), однако в последнее время (по крайней мере, для отдельных временных отрезков) магматизм в Охотско-Чукотском поясе интерпретирован как проявившийся в условиях скольжения литосферных плит (Ханчук и др., 2019). Обстановку скольжения литосферных плит мы реконструируем для Южно-Анюйской сутурной зоны и Олойского пояса, в которых находится крупнейшее на Дальнем Востоке РФ медномолибден-порфировое месторождение Песчанка, генетически связанное с монцонитоидами Егдэгкычского плутона берриас-валанжинского возраста (Нагорная, 2013; Amato et el., 2015; Кара, 2018). С ранне- и позднемеловыми гранитоидами Удско-Мургальской дуги и перекрывающего его альб-кампанского Охотско-Чукотского вулканогенного пояса также связаны проявления меднопорфировых руд (рис. 1).

Наиболее известное и частично разведанное на сегодня рудопроявление Лора (ресурсы более 1 млн т Cu) расположено на п-ове Кони-Пьягина (Колова, Савва, 2008). Рудоносный штокверк концентрируется в сеноманском Среднинском гранитоидном массиве (см. рис. 1). В целом для магматических пород п-ова Кони-Пьягина установлены K-Ar возрасты от 180 до 80 млн лет (Акинин, Котляр, 1997), что предварительно свидетельствует о наложении здесь альб-кампанского ОЧВП на юрско-раннемеловую Удско-Мургальскую магматическую дугу (рис. 2).

Надежное определение возраста с использованием более точных U-Pb и Ar-Ar методов датирования будет способствовать научно обоснованной прогнозной оценке перспективности тех или иных магматических комплексов.

В северной части Коркодоно-Наяханской металлогенической зоны недавно выполнены поисково-разведочные работы на перспективном Мо-порфировом рудопроявлении Ак-Су (см. рис. 1). Эта металлогеническая зона охватывает цепочку выходов известково-щелочных гранитоидов наяханского комплекса коньяк- 
Pис. 1. Тектоническая схема Северного Приохотья (по: С. М. Тильман, Н. А. Богданов, 1992, с изменениями) с районами проявлений $\mathrm{Cu}$-порфировой минерализации и обсуждаемыми в тексте интрузиями месторождений: 1 - Омолонский кратонный блок и Приколымский блок; 2 - триасовоюрские терригенные комплексы (мезозоиды); 3 - позднедевонские вулканические ареалы кедонской серии; 4 - позднеюрскораннемеловые окраинно-континентальные вулканические пояса и островные дуги; 5 - альб-кампанский Охотско-Чукотский вулкано-плутонический пояс; 6 - палеогеннеогеновый Западно-Камчатский вулканический пояс; 7 - неоген-четвертичные молассы. Темно-серые - интрузивные массивы

Fig. 1. Tectonic map of Northern Priokhotye (after Til'man \& Bogdanov, 1992, with alterations), showing the areas of Cu-porphyry miner-

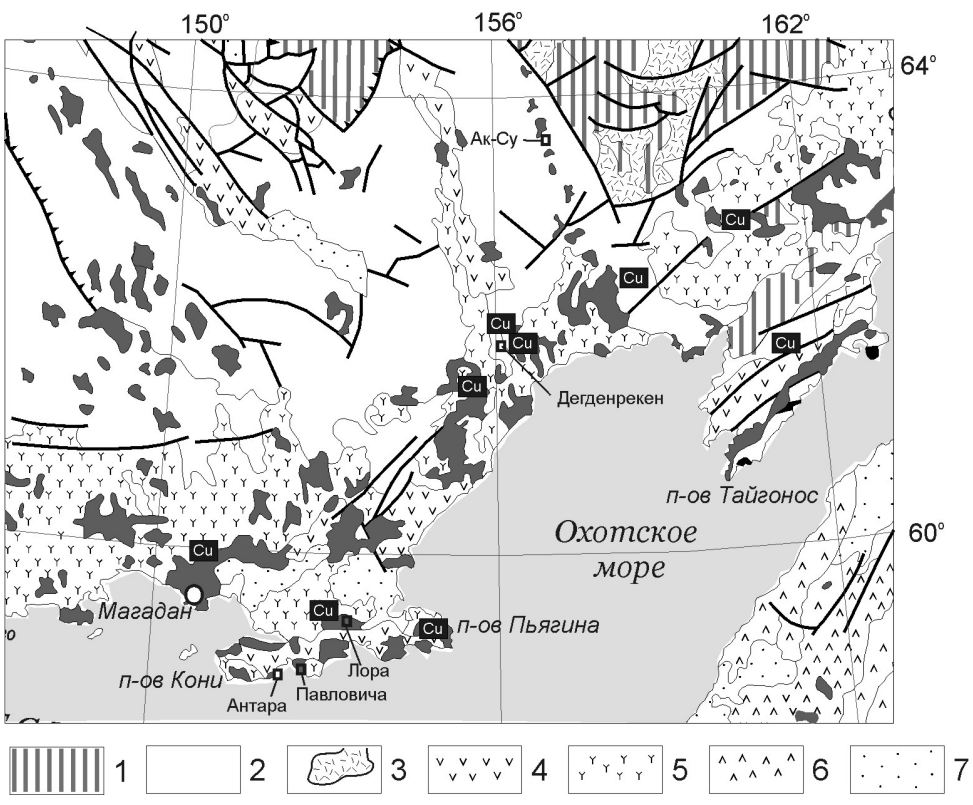
alization occurrences and deposit intrusions discussed: 1 - Omolon craton block and Prikolymye block; 2 - Triassic-Jurassic terrigenous complexes (mesozoids); 3 - Upper Devonian volcanic areas of the Kedon formation; 4 - Late Jurassic - Early Cretaceous margin-continental volcanic belts and island arcs; 5 - Okhotsk-Chukotka volcanic belt (Albian to Campanian); 6 - Paleogene-Neogene West Kamchatka volcanic belt; 7 - Neogene-Quaternary molasses. Dark-grey are insturive plutons

сантонского возраста, которая простирается ортогонально к генеральной структуре надсубдукционного ОЧВП вдоль западной границы Омолонского кратонного массива. Ранее нами был определен близкий возраст гранитоидов и молибденовой минерализации, обоснована их генетическая связь (Акинин и др., 2019).

В центральной части ОЧВП, около смыкания его с апт-альбским Балыгычано-Сугойским прогибом, который также ортогонально протягивается к генеральной структуре пояса, известно рудопроявление Дегденрекен (см. рис. 1). Летом 2019 г. мы провели здесь рекогносцировочные работы, оценив перспективы этого проявления положительно. В районе рудопроявления алевролиты и песчаники средней юры прорваны штоком, сложенным в центральной части порфировидными гранодиоритами, кварцевыми монцонитами и монцогаббро, а на периферии - эксплозивными брекчиями. Рудоносный штокверк размером в плане $1.4 \times 1.0$ км окружен ореолом серицити-

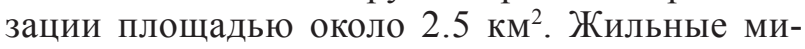
нералы: кварц, хлорит, серицит, эпидот, кальцит, турмалин, актинолит, альбит, пирофиллит, алунит. Рудная минерализация: пирит, халькопирит, молибденит, борнит, сфалерит, галенит, арсенопирит, гематит, кобальтин, касситерит, шеелит, самородное золото. Средние содержания $\mathrm{Cu}$ составляют $0.46 \%$, Мо - 0.019\%, Аu - 0.05 г/т, $\mathrm{Ag}-1$ г/т. Вертикальный размах оруденения превышает 300 м. Прогнозные ресурсы меди оцениваются в 2 млн т (В. И. Родионов, 2004 г.).

На побережье Охотского моря в пределах альб-кампанского Охотско-Чукотского окраинно-

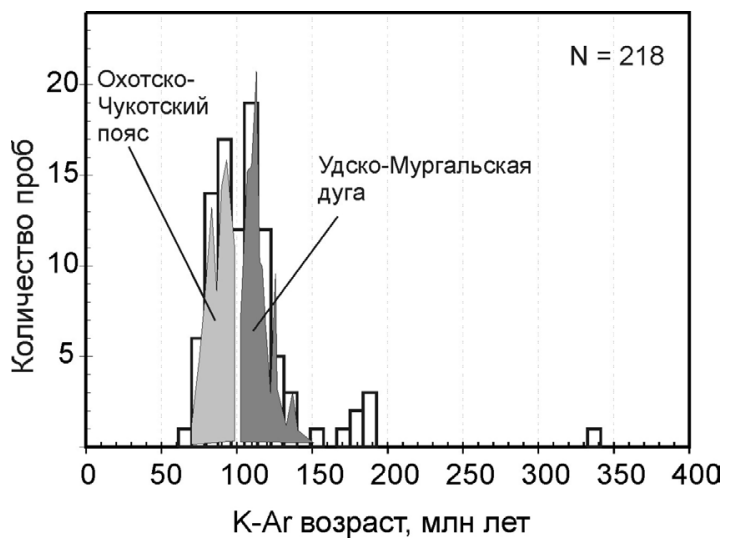

Puc. 2. Гистограмма K-Ar датировок магматических пород п-ова Кони-Пьягина (лист О-56). База данных «Геохрон-1» (Акинин, Котляр, 1997)

Fig. 2. Histogram of K-Ar dating of magmatic rocks from the Koni-Pyyagina Peninsula (Sheet O-56). "Geochron-1" database (Akinin, Kotlyar, 1997)

континентального пояса (см. рис. 1) известно еще не менее 13 медно-порфировых проявлений, которые на сегодня очень слабо исследованы и не оценены.

\section{РЕЗУЛЬТАТЫ}

По химическом составу интрузивные (плутонические и субвулканические) породы рассматриваемых магматических поясов принадлежат к известково-щелочным низко- и высококалиевым сериям, для многих чукотских интрузий характерна принадлежность к шошонитовой серии. Повышенной щелочностью и монцонитоидны- 
ми трендами характеризуются интрузивные породы Олойского пояса (Егдэгкычский и Тополевский массивы, в которых концентрируются $\mathrm{Cu}$-порфировые месторождения Песчанка и $\mathrm{Be}$ сеннее) - рис. 3,a

Всем породам на спайдер-диаграммах, нормированных к примитивной мантии, свойствен обогащенный высокозарядными элементами спектр с ясно выраженными негативными ано-

a
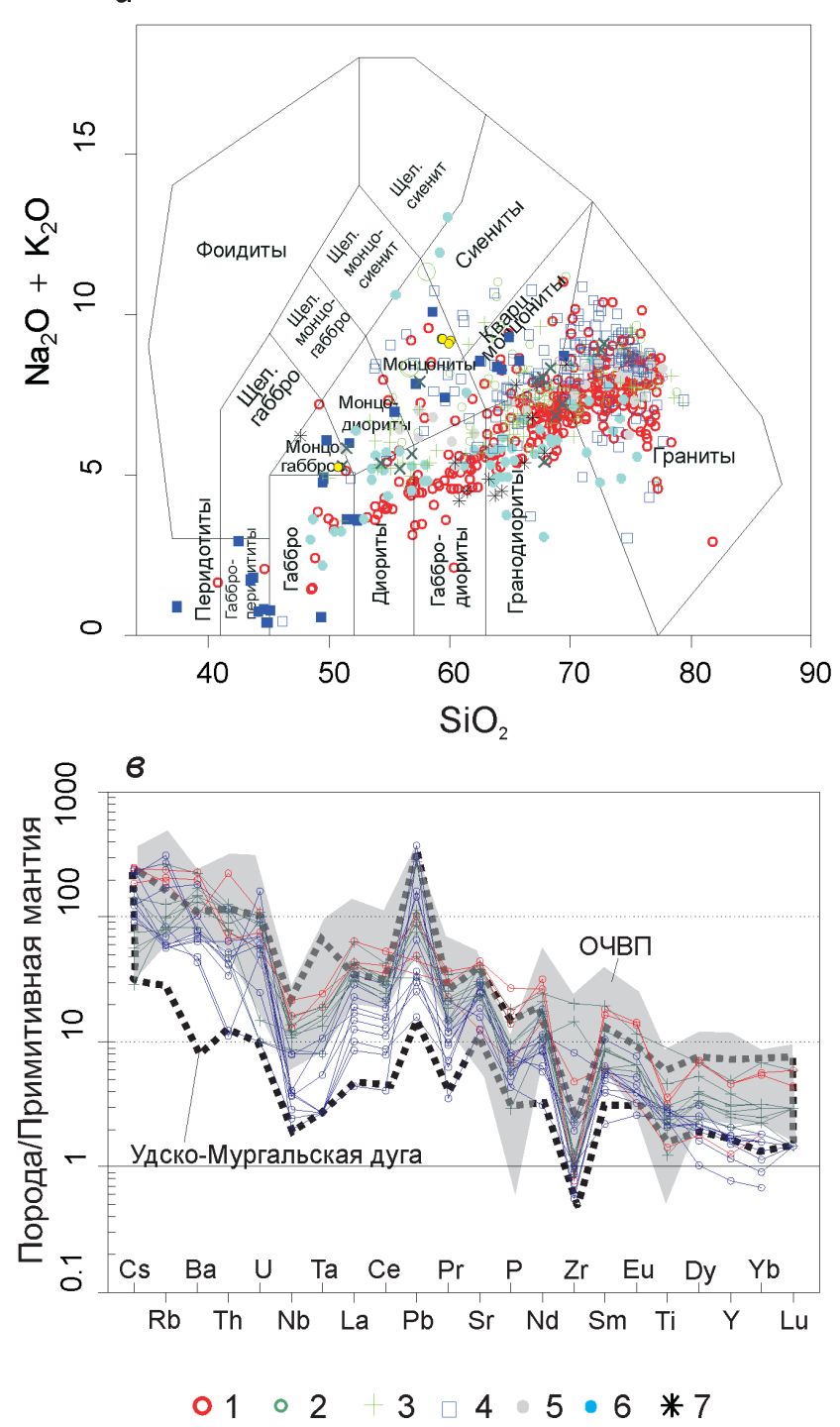

малиями $\mathrm{Nb}, \mathrm{Ta}, \mathrm{P}$ и $\mathrm{Zr}$ и положительной аномалией $\mathrm{Pb}$ (рис. 3,в). Такие геохимические особенности обычны в надсубдукционных магмах окраинно-континентальных и островодужных поясов. Для большинства пород характерны умеренные $\mathrm{La} / \mathrm{Yb}$ и $\mathrm{Sr} / \mathrm{Y}$ отношения, слабые «адакитовые» геохимических метки устанавливаются для гранитоидов на месторождениях Лора и Ак-Су (рис. 3,2).
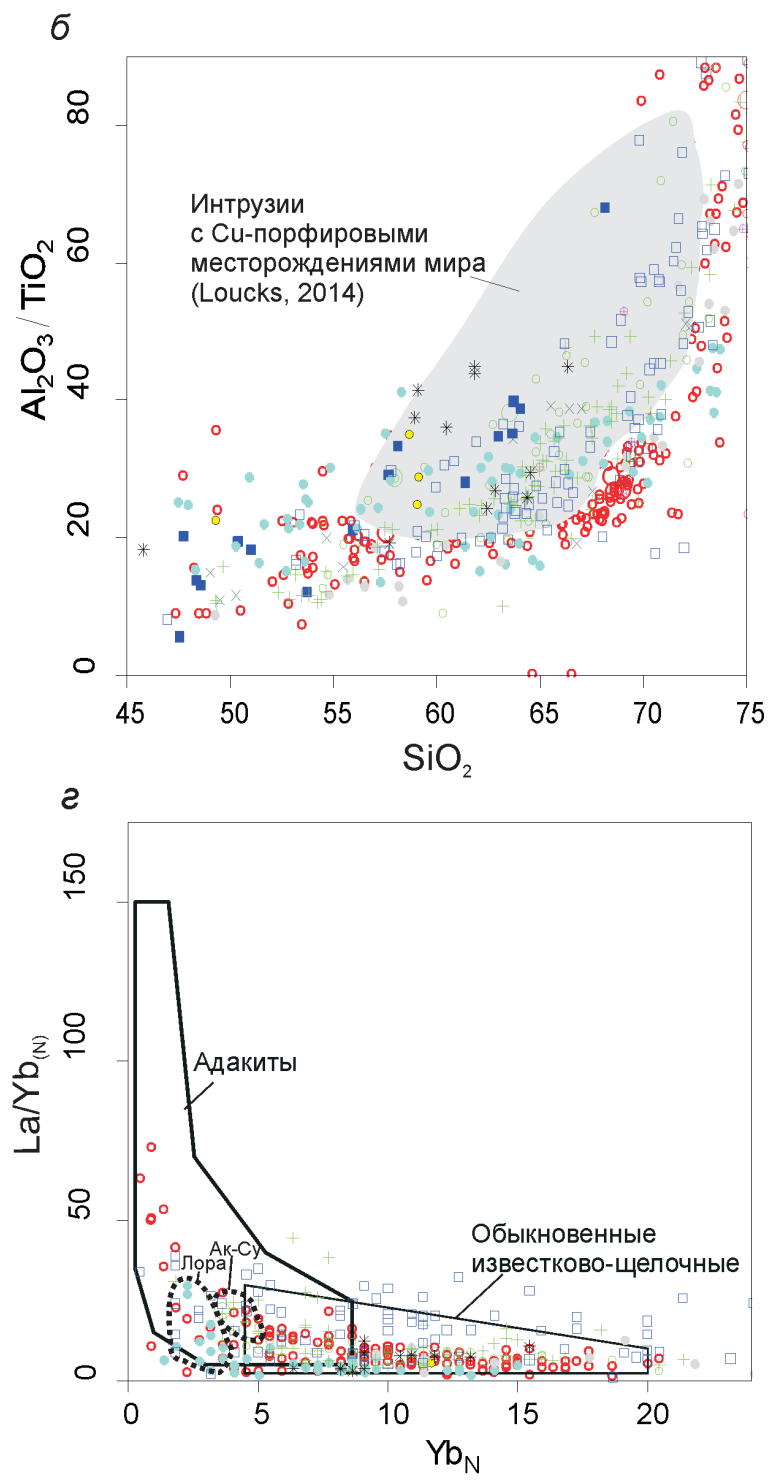

Puc. 3. Химический состав горных пород главных магматических поясов Северо-Востока России: 1 - Главный Колымский пояс юрских гранитных батолитов; 2 - позднемеловые плутоны гранитоидов в поле Главного Колымского пояса; 3 - альб-коньякские гранитоиды охотского комплекса в Охотско-Чукотском вулканоплутоническом поясе; 4 - гранитоиды Чукотского пояса; 5, 6 - Удско-Мургальская дуга (5 - внешняя, континентальная зона, 6 - внутренняя, «приокеаническая» зона); 7 - гранитоиды Cu-порфирового месторождения Малмыж в Приморье (Soloviev et al., 2019). На рис. 4,в показаны спектры распределения примесных некогерентных элементов только для образцов с $\mathrm{Sr} / \mathrm{Y}>35$

Fig. 3. Chemical composition of magmatic rocks from major magmatic belts in the North-East of Russia: 1 - Main Kolyma belt of Jurassic granite batholites; 2 - Upper Cretaceous granitoid plutons within the Main Kolyma belt; 3 Albian-Coniacian granitoids of the Okhotsk Complex in the Okhotsk-Chukotka volcanic belt; 4 - granitoids of the Chukotka belt; 5, 6-Uda-Murgal island arc (5 - outer, continental zone; 6-inner, "by-the-ocean" zone); 7 - granitoid rocks of Malmyzh Cu-porphyry deposit in Primorye (Soloviev et al., 2019). Fig. 4,6 shows distribution spectra for incompatible trace elements only for samples with $\mathrm{Sr} / \mathrm{Y}>35$ 
Наиболее интересные и «работающие» для металлогенического прогноза геохимические характеристики магм предложены Робертом Лаксом (Loucks, 2014). Им установлено, что подавляющее большинство $\mathrm{Cu}$-порфировых месторождений ассоциирует с интрузиями, в породах которых устанавливаются высокие $\mathrm{Sr} / \mathrm{Y}$ (более 35 ) и $\mathrm{V} / \mathrm{Sc}$ отношения. Для второго предложен параметр $\mathrm{V} / \mathrm{Sc}>32.5-0.385 \times \mathrm{SiO}_{2}$. Оба геохимических трассера выведены на основе анализа 135 крупных мировых месторождений. В работе (Chiaradia, Caricchi, 2017) проведено моделирование эволюции гидротермальномагматической рудной системы методом МонтеКарло и установлено, что наиболее крупные по запасам (более 70 млн т $\mathrm{Cu}$ ) месторождения формируются из магм с высоким $\mathrm{Sr} / \mathrm{Y}$ отношением и общей длительностью рудоотложения не менее 1.5-2 млн лет.

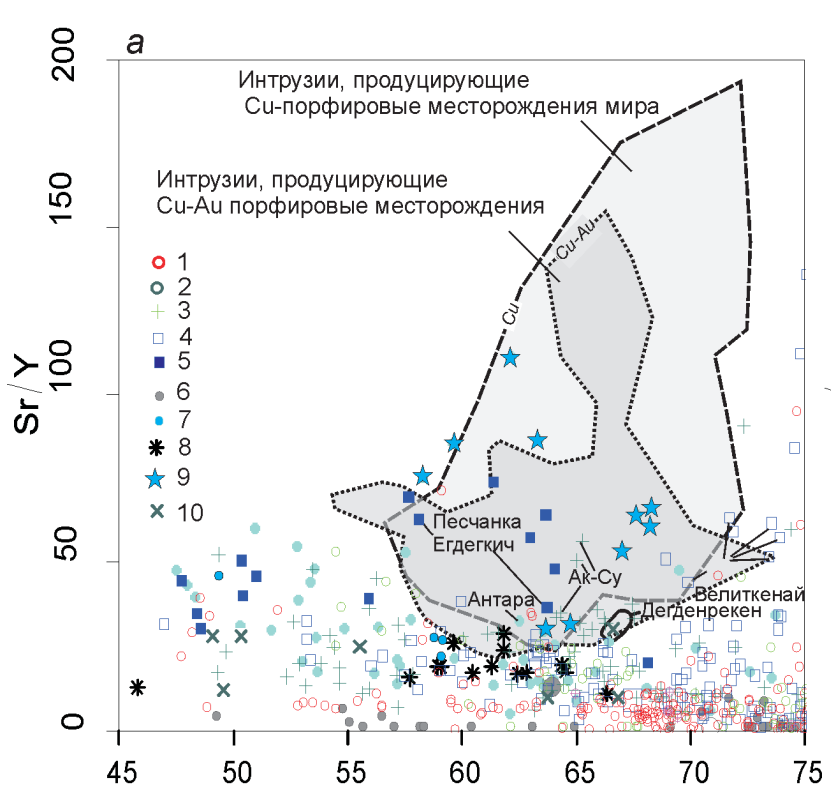

В магматических породах Северо-Востока России $\mathrm{Sr} / \mathrm{Y}$ отношение обычно невысокое, превышает 35 ед. только для таких объектов, как Егдэгкычский плутон в Олойской зоне Чукотки $(\mathrm{Cu}$-порфировое месторождение Песчанка), Среднинский гранитоидный массив на п-ове Кони-Пьягина (Cu-порфировое месторождение Лора), плутоны Сабля и Безымянный в Коркодоно-Наяханской зоне ОЧВП (Мо-порфировое месторождение Ак-Су и ассоциирующие с ним золото-редкометалльные проявления) (рис. 4,a).

Перспективность вышеописанных магматических комплексов также хорошо выделяется и на диаграмме $\mathrm{SiO}_{2}-\mathrm{V} / \mathrm{Sc}$ (рис. 4,б). Около нижней дискриминантной границы по $\mathrm{Sr} / \mathrm{Y}$ располагаются фигуративные точки составов интрузий из $\mathrm{Cu}$ порфирового месторождения Малмыж в Приморье и перспективного слабоизученного проявления Дегденрекен (рис. 4,a).

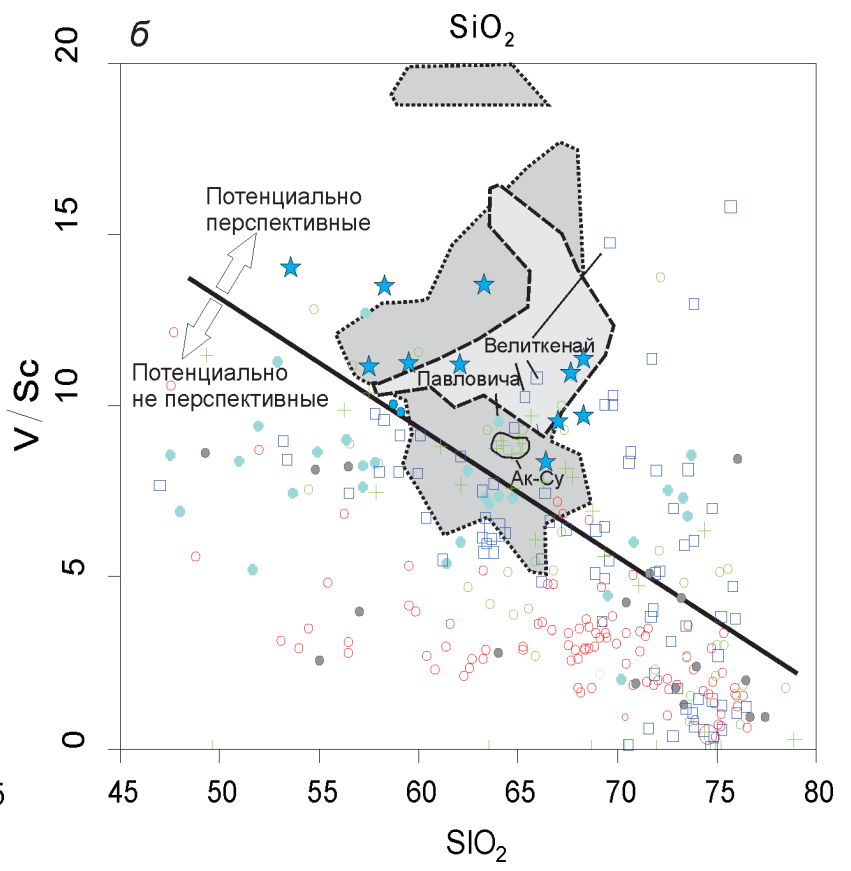

Puc. 4. Вариации $\mathrm{Sr} / \mathrm{Y}$ и V/Sc отношений в зависимости от концентраций $\mathrm{SiO}_{2}$ в магматических породах Северо-Востока России. Магматические пояса и $\mathrm{Cu}$-порфировые месторождения: 1 - Главный Колымский пояс юрских гранитных батолитов; 2 - позднемеловые плутоны гранитоидов в поле Главного Колымского пояса; 3 - альб-коньякские гранитоиды Охотско-Чукотского вулкано-плутонического пояса; 4 - альбаптские гранитоиды Чукотского пояса; 5 - Олойский пояс, валанжин-берриасский егдэгкычский комплекс; 6, 7 - Удско-Мургальская дуга (6 - внешняя, 4 - внутренняя); 8 - гранитоиды Cu-порфирового месторождения Малмыж в Приморье (Soloviev et al., 2019); 9 - позднемеловые гранитоиды Среднинского массива, $\mathrm{Cu}$-порфировое месторождение Лора; 10 - позднемеловые диорит-порфиры месторождения Дегденрекен. Серые поля - интрузии, в которых сконцентрированы крупнейшие $\mathrm{Cu}$-порфировые месторождения мира (Loucks, 2014)

Fig. 4. Variations of $\mathrm{Sr} / \mathrm{Y}$ и $\mathrm{V} / \mathrm{Sc}$ ratios depending on $\mathrm{SiO}_{2}$ content in magmatic rocks of Russia's North-East: 1 - Main Kolyma belt of Jurassic granite batholites; 2 - Late Cretaceous granite plutons in the Main Kolyma belt; 3 -Albian-Coniacian granitoids of the Okhotsk-Chukotka volcanic belt; 4 -Albian-Aptian granitoids of the Chukotka belt; 5 - Oloy belt, Valanginian-Berriassian Yegdegkych Complex; 6, 7 - Uda-Murgal arc (6 - outer, 7 - inner); 8 - granitoids of the Malmyzh Cu-porphyry deposit (Soloviev et al., 2019); 9 - Late Cretaceous granitoids of the Sredninsky pluton, Lora Cu-porphyry deposit; 10 - Late Cretaceous diorite-porphyries of the Degdenreken deposit. The gray fields are intrusions hosting the world's largest Cu-porphyry deposits (Loucks, 2014) 


\section{ВЫВОДЫ}

Раннемеловые магматические комплексы в Удско-Мургальском и Охотско-Чукотском магматических поясах Магаданской области и Олойском магматическом поясе на Чукотке характеризуются умеренно обогащенным высокозарядными элементами спектром распределения примесных элементов с ясно выраженными негативными аномалиями $\mathrm{Nb}, \mathrm{Ta}, \mathrm{P}$ и $\mathrm{Zr}$ и положительной аномалией $\mathrm{Pb}$, умеренным $\mathrm{La} / \mathrm{Yb}$, свойственными надсубдукционным обстановкам андийского типа. Для ряда магматических пород в интрузиях установлены высокие $\mathrm{Sr} / \mathrm{Y}$ и V/Sc отношения, что позволяет отнести их к перспективным на обнаружение новых $\mathrm{Cu}$-порфировых месторождений.

Геохимические критерии $\mathrm{Sr} / \mathrm{Y}>35$ при $\mathrm{SiO}_{2}=$ 57-72 мас.\% и V/Sc > 32.5-0.385 × $\mathrm{SiO}_{2}$ (Loucks, 2014) рудоносных магм, с которыми генетически связаны медно-порфировые с золотом месторождения мира, в совокупности с надежным определением возраста могут быть использованы для выработки научно обоснованных подходов при оценке перспективности тех или иных магматических комплексов, а также успешно использованы для проспекторских работ.

Исследования выполнены при поддержке гранта № 18-2-015 комплексной программы ДВО РАН «Дальний Восток».

\section{ЛИТЕРАТУРА}

Акинин В. В., Колова Е. Е., Савва Н. Е., Горячев Н. А., Маматюсупов В. Т., Кузнецов В. М., Альшевский А. В., Ползуненков Г. О. Возраст гранитоидов и ассоциирующего молибден-порфирового оруденения Коркодон-Наяханской зоны, Северо-Восток России // Вестник СВНЦ ДВО РАН. 2019. № 4. С. 3-8. DOI: 10.34078/1814-0998-2019-4-39-44

Акинин В. В., Котляр И. Н. ГЕОХРОН компьютерная база данных изотопного датирования минералов, горных пород и руд Северо-Востока России // Магматизм и оруденение Северо-Востока России / под ред. С. Г. Бялобжеского. Магадан : СВКНИИ ДВО РАН, 1997. С. 313-318.

Акинин В. В., Миллер Э. Л. Эволюция известковощелочных магм Охотско-Чукотского вулканогенного пояса // Петрология. 2011. Т. 19, № 3. C. 249-290. DOI: $10.1134 / \mathrm{S} 0869591111020020$

Горячев Н. А., Бердников Н. В. Типы рудоносных гранитов юго-восточной части мезозоид СевероВостока России и их флюидная специализация // Тихоокеанская геология. 2006. Т. 25, № 3. С. 40-52.

Kapa T. B. Новые данные о возрасте магматических комплексов Алазейско-Олойской складчатой системы (западная Чукотка) // Там же. 2018. Т. 37, № 6. C. $107-115$.

Колова E. Е., Савва Н. Е. Соотношение медномолибден-порфирового и золотого оруденения на П-овах Кони и Пьягина (Северное Приохотье) // Вестник СВНЦ ДВО РАН. 2008. № 4. С. 2-15.
Нагорная Е. В. Минералогия изональность молибденмедно-порфирового рудного поля Находка, Чукотка : автореф. дис. ... канд. геол.-минер. наук. М., 2013. 27 с.

Парфенов Л. М. Континентальные окраины и островные дуги мезозоид северо-востока Азии. Новосибирск : Наука, 1984. 191 с.

Трунилина В. А., Роев С. П., Орлов Ю. С., Зайцев А. И., Оксман В. С., Хабибулина Т. С. Вулканоплутонические пояса северо-востока ВерхояноКолымских мезозоид. Якутск : Сахаполиграфиздат, 2007. 152 c.

Ханчук А. И., Гребенников А. В., Иванов В. В. Альб-сеноманский окраинно-континентальный орогенный пояс и магматическая провинция Тихоокеанской Азии // Тихоокеанская геология. 2019. Т. 38, № 3. C. 4-37.

Шиикерман В. И., Полуботко И. В., Васькин А. Ф., Петухов В. В., Желебогло О. В., Лебедева О. Ю., Иванова Т. К., Макар В. И., Казакова Г. Г. Государственная геологическая карта Российской Федерации. Масштаб 1 : 1000000 (3-е поколение). Сер. Верхояно-Колымская. Лист Р-55 - Сусуман. Объяснительная записка. СПб. : Изд-во СПб. ; Картограф. фабрика ВСЕГЕИ, 2016.

Amato J. M., Toro J., Akinin V. V., Hampton B. A., Salnikov A. S., Tuchkova M. I. Tectonic evolution of the Mesozoic South Anyui suture zone, eastern Russia: A critical component of paleogeographic reconstructions of the Arctic region // Geosphere. 2015. Vol. 11, No. 5. P. 1530 1564.

Chiaradia M. Crustal thickness control on $\mathrm{Sr} / \mathrm{Y}$ signatures of recent arc magmas: an Earth scale perspective // Scientific Reports. 2015. Vol. 5. 8115. DOI: 10.1038/srep08115

Chiaradia M., Merino D., Spikings R. Rapid transition to long lived deep crustal magmatic maturation and the formation of giant porphyry-related mineralization Yanacocha, Peru // Earth Planet Sci. Lett. 2009. 288:505515.

Chiaradia M., Caricchi L. Stochastic modelling of deep magmatic controls on porphyry copper deposit endowment // Scientific Reports. 2017. Vol. 7. 44523. DOI: $10.1038 /$ srep44523

Chiaradia M., Ulianov A., Kouzmanov K., Beate B. Why large porphyry $\mathrm{Cu}$ deposits like high $\mathrm{Sr} / \mathrm{Y}$ magmas? // Nature. 2012. 685:1-7.

Hedenquist $J$. W., Lowenstern J. B. The role of magmas in the formation of hydrothermal ore deposits // Ibid. 1994. 370:519-527.

Kay S., Mpodozis C., Ramos V. A., Munizaga F. Magma source variations for mid-late Tertiary magmatic rocks associated with a shallowing subduction zone and a thickening crust in the central Andes ( 28 to $\left.33^{\circ} \mathrm{S}\right) / /$ Andean magmatism and its tectonic setting / Eds. R. S. Harmon, C. W. Rapela. Boulder, Colorado. Spec. Pap. Geol. Soc. Am. 1991. 265. P. 113-137.

Layer P. W., Newberry R., Fujita K., Parfenov L., Trunilina $V$., Bakharev A. Tectonic Setting of the Plutonic Belts of Yakutia, Northeast Russia, Based on ${ }^{40} \mathrm{Ar} /{ }^{39} \mathrm{Ar}$ Geochronology and Trace Element Geochemistry // Geology. 2001. 29 (2). P. 167-170.

Loucks R. R. Distinctive composition of copperore-forming arc magmas // Aust. J. Earth Sci. 2014. 61. P. 5-16. 
Oyarzun R., Marquez A., Lillo J., Lopez I., Rivera S. Giant versus small porphyry copper deposits of Cenozoic age in northern Chile: adakitic versus normal calc-alcaline magmatism // Miner. Deposita. 2001. 36. P. 794-798.

Pettke T., Oberli F., Heinrich C. A. The magma and metal source of giant porphyry-type ore deposits, based on lead isotope microanalysis of individual fluid inclusions // Earth Planet Sci. Lett. 2010. 296. P. 267-277.

Richards J. P. Tectono-magmatic precursors for porphyry $\mathrm{Cu}-\mathrm{Mo}-\mathrm{Au}$ deposit formation // Econ. Geol. 2003. 98. P. 1515-1533.
Sillitoe R. H. A plate tectonic model for the origin of porphyry copper deposits // Econ. Geol. 1972. 67. P. 184-197.

Sillitoe R. H., Perelly J. Andean copper province: Tectonomagmatic settings, deposit types, metallogeny, exploration, and discovery // Ibid. 2005. $100^{\text {th }}$ Anniversary Volume. P. 845-890.

Soloviev S. G., Kryazhev S. G., Dvurechenskaya S. S., Vasyukov V. E., Shumilin D. A., Voskresensky K. I. The superlarge Malmyzh porphyry $\mathrm{Cu}-\mathrm{Au}$ deposit, SikhoteAlin, eastern Russia: Igneous geochemistry, hydrothermal alteration, mineralization, and fluid inclusion characteristics // Ore Geology Reviews. 2019. 113. P. 103112.

Поступила в редакиию 16.12.2019 2.

Поступила после доработки 25.12.2019 2.

\title{
GEOCHEMICAL CRITERIA OF CALC-ALKALINE INTRUSION MAGMAS, PERSPECTIVE ON DISCOVERY OF COPPER-PORPHYRY ORE DEPOSITS IN THE NORTH-EAST OF RUSSIA
}

\author{
V. V. Akinin', N. V. Berdnikov', G. O. Polzunenkov', A. N. Glukhov ${ }^{I}$, E. E. Kolova ${ }^{1}$ \\ ${ }^{I}$ North-East Interdisciplinary Scientific Research Institute n. a. N. A. Shilo, FEB RAS, Magadan \\ ${ }^{2}$ Institute of Tectonics and Geophysics n. a. Yu. A. Kosygin, Khabarovsk
}

Geochemistry of calc-alkaline intrusive rocks from main Mesosoic magmatic belts (Kolyma, Chukotka, Oloy, Uda-Murgal, Okhotsk-Chukotka) in the North-East of Russia is briefly characterized. Using the known geochemical signatures $(\mathrm{Sr} / \mathrm{Y}$ and $\mathrm{V} / \mathrm{Sc})$ of ore-bearing magmas, genetically associated with world's copper-porphyry deposits with gold, we have identified the most perspective Early Cretaceous magmatic complexes in Magadan Oblast and Chukotka (Okhotsk, Nayakhan, and Yegdegkych).

Keywords: copper porphyry deposits, arc magmatism, geochemistry, criteria, North-East of Russia.

\section{REFERENCES}

Akinin, V. V.; Kotlyar, I. I., 1997, GEOCHRON Computerized Database of Isotopic Dating of Minerals, Rocks, and Ores in the North-East of Russia, Magmatism and Mineralization of Russia's North-East, Ed. S. G. Byalobzhesky, Magadan, NEISRI FEB RAS, 313-318 [In Russian].

Akinin, V. V.; Kolova, E. E.; Savva, N. E.; Goryachev, N. A.; Mamatyusupov, V. T.; Kuznetsov, V. M.; Alshevsky, A. V.; Polzunenkov, G. O., 2019, Age of Granitoids and the Associated Molibdenum-Porphyry Mineralization in the Korkodon-Nayakhan Zone, North-East of Russia, Bulletin of the North-East Science Center, 4, 3-8, DOI: 10.34078/1814-0998-2019-4-39-44 [In Russian].

Akinin, V. V.; Miller, E. L., 2011, Evolution of CalcAlkaline Magmas of the Okhotsk-Chukotka Volcanic Belt, Petrology, 19 (3), 237-277, DOI: 10.1134/ S0869591111020020

Amato, J. M.; Toro, J.; Akinin, V. V.; B. A., Hampton B. A., Salnikov A. S., Tuchkova M. I., 2015, Tectonic Evolution of the Mesozoic South Anyui Suture Zone, Eastern Russia: A Critical Component of Paleogeographic Recon- structions of the Arctic Region, Geosphere, 11, 5, 15301564.

Chiaradia, M., 2015, Crustal Thickness Control on Sr/Y Signatures of Recent Arc Magmas: an Earth Scale Perspective, Scientific Reports, 5, 8115, DOI: 10.1038/ srep08115

Chiaradia, M.; Caricchi, L., 2017, Stochastic Modelling of Deep Magmatic Controls on Porphyry Copper Deposit Endowment, Ibid., 7, 44523, DOI: 10.1038/ srep44523

Chiaradia, M.; Merino, D.; Spikings, R., 2009, Rapid transition to Long Lived Deep Crustal Magmatic Maturation and the Formation of Giant Porphyry-Related Mineralization Yanacocha, Peru, Earth Planet Sci. Lett., 288, 505-515.

Chiaradia, M.; Ulianov, A.; Kouzmanov, K.; Beate, B., 2012, Why Large Porphyry $\mathrm{Cu}$ Deposits Like High $\mathrm{Sr} / \mathrm{Y}$ magmas? Nature, 685, 1-7.

Goryachev, N. A., Berdnikov, N. V., 2006, Types of OreBearing Granites of the South-Eastern Part of Mesozoides of Russia's North-East, and Their Fluid Specialization, Tikhookeanskaya Geologiya, 25 (3), 40-52 [In Russian]. 
Hedenquist, J. W.; Lowenstern, J. B., 1994, The Role of Magmas in the Formation of Hydrothermal Ore Deposits, Nature, 370, 519-527.

Kara, T. V., 2018, New Data on the Age of Igneous Complexes of the Alazey-Oloy Foldbelt (Western Chukotka), Russian Journal of Pacific Geology, 12 (6), 549-557.

Kay, S.; Mpodozis, C.; Ramos, V. A.; Munizaga, F., 1991, Magma Source Variations for Mid-Late Tertiary Magmatic Rocks Associated with a Shallowing Subduction Zone and a Thickening Crust in the Central Andes $\left(28-33^{\circ} \mathrm{S}\right)$, Andean Magmatism and Its Tectonic Setting, Eds. R. S. Harmon, C. W. Rapela, Boulder, Colorado, Spec. Pap. Geol. Soc. Am., 265, 113-137.

Khanchuk, A. I.; Grebennikov, A. V.; Ivanov, V. V., 2019, Alb-Cenomanian Marginal Continental Orogenic Belt and the Magmatic Province of Pacific Asia, Tikhookeanskaya Geologiya, 38 (3), 4-37 [In Russian].

Kolova, E. E., Savva, N. E., 2008, Ratio of Copper-Molybdenum-Porphyry and Gold Mineralization in the Koni and Pyagina Peninsulas, Northern Priokhotye, Vestnik NESC FEB RAS, 4, 2-15 [In Russian].

Layer, P. W.; Newberry, R.; Fujita, K.; Parfenov, L.; Trunilina, V.; Bakharev, A., 2001, Tectonic Setting of the Plutonic Belts of Yakutia, Northeast Russia, Based on ${ }^{40} \mathrm{Ar} /{ }^{39} \mathrm{Ar}$ Geochronology and Trace Element Geochemistry, Geology, 29 (2), 167-170.

Loucks, R. R., 2014, Distinctive Composition of Copper-Ore-Forming Arc Magmas, Aust. J. Earth Sci., 61, 5-16.

Nagornaya, Ye. V., 2013, Mineralogy and Zonality of the Nakhodka Molybdenum-Copper-Porphyry Ore Field, Chukotka, Author's Abstr. Diss. ... Cand. Sci. (Geology \& Mineralogy), Moscow [In Russian].

Oyarzun, R.; Marquez, A.; Lillo, J.; Lopez, I.; Rivera, S., 2001, Giant Versus Small Porphyry Copper Deposits of Cenozoic Age in Northern Chile: Adakitic Versus
Normal Calc-Alcaline Magmatism, Miner. Deposita, 36, 794-798.

Parfenov, L. M., 1984, Continental Margins and Island Arcs in the Mesozoids of Northeast Asia, Novosibirsk, Nauka [In Russian].

Pettke, T.; Oberli, F.; Heinrich, C. A., 2010, The Magma and Metal Mource of Giant Porphyry-Type Ore Deposits, Based on Lead Isotope Microanalysis of Individual Fluid Inclusions, Earth Planet Sci. Lett., 296, 267-277.

Richards, J. P., 2003, Tectono-Magmatic Precursors for Porphyry $\mathrm{Cu}-\mathrm{Mo}-\mathrm{Au}$ Deposit Formation, Econ. Geol., 98, 1515-1533.

Shpikerman, V. I.; Polubotko, I. V.; Vas 'kin, A. F.; Petukhov, V. V.; Zheleboglo, O. V.; Lebedeva, O. Yu.; Ivanova, T. K.; Makar, V. I.; Kazakova, G. G., 2016, State Geological Map of the Russian Federation, Scale 1:1 000000 ( $3^{\text {rd }}$ Generation), Verkhoyansk-Kolyma Series, Sheet O-55, St. Petersburg, VSEGEI [In Russian].

Sillitoe, R. H., 1972, A Plate Tectonic Model for the Origin of Porphyry Copper Deposits, Econ. Geol., 67, 184-197.

Sillitoe, R. H.; Perelly, J., 2005, Andean Copper Province: Tectonomagmatic Settings, Deposit Types, Metallogeny, Exploration, and Discovery, Ibid., $100^{\text {th }}$ Anniversary Volume, 845-890.

Soloviev, S. G.; Kryazhev, S. G.; Dvurechenskaya, S. S.; Vasyukov, V. E.; Shumilin, D. A.; Voskresensky, K. I., 2019, The Superlarge Malmyzh Porphyry Cu-Au Deposit, Sikhote-Alin, Eastern Russia, Igneous Geochemistry, Hydrothermal Alteration, Mineralization, and Fluid Inclusion Characteristics, Ore Geology Reviews, 113, 103-112.

Trunilina, V. A.; Royev, S. P.; Orlov, Yu. S., Zaytsev, A. I.; Oksman, V. S.; Khabibulina, T. S., 2007, VolcanicPlutonic Belts of Yakutia's North-East, Yakutsk, Sakhapoligrafizdat [In Russian]. 